\title{
SOBRE AS EXPERIÊNCIAS DE COMENSALIDADES DE IMIGRANTES BRASILEIROS E PARAENSES EM BARCELONA
}

\author{
Miguel de Nazaré Brito Picanço ${ }^{1}$
}

\begin{abstract}
RESUMO
Este artigo é de cunho etnográfico e se inscreve no âmbito do meu Pós-doutorado em Antropologia da Alimentação, instância levada a cabo no período de julho de 2018 a janeiro de 2019, no Observatorio de la Alimentação, na Universidade de Barcelona, cujo objetivo é descrever e analisar, por meio de narrativas textuais e imagéticas, as experiências de comensalidades vivificadas por brasileiros, em particular pelos paraenses, que vivem Barcelona. Por meio de observação em campo, conversas e entrevistas, pode-se notar que os comportamentos alimentares dos imigrantes que habitam em Barcelona constituem-se em recursos políticos de resistência e afirmação frente a outros contextos alimentares.
\end{abstract}

Palavras-chave: Comida brasileira. Migração. Comensalidades. Resistência.

\section{CONCERNING THE COMMENSALITY EXPERIENCES OF BRAZILIAN AND STATE OF PARÁ IMMIGRANTS IN BARCELONA}

\begin{abstract}
This article is of an ethnographic nature and falls under the scope of my Post-doctorate in Anthropology of Food, an instance carried out from July 2018 to January 2019, at the Observatory of Food, at the University of Barcelona, whose objective is describe and analyze, through textual and imagery narratives, the experiences of commensalities enlivened by Brazilians, in particular by paraenses, who live in Barcelona. Through field observation, conversations and interviews, it can be noted that the eating behaviors of immigrants living in Barcelona constitute political resources of resistance and affirmation in relation to other food contexts.
\end{abstract}

Keywords: Brazilian food. Migration. Commensalities. Resistance

Data de submissão: 14.03 .2021

Data de aprovação: 30.04 .2021

\section{INTRODUÇÃO}

Com a intensificação recente dos processos globais, os fluxos migratórios de bens alimentícios em escala transnacional foram potencializados, provocando um reordenamento no campo alimentar, intensificando a circulação dos alimentos, que em movimentos contínuos e graduais acompanham cada vez mais as pessoas em escalas transnacionais, implicando considerável impacto no campo da alimentação. Neste caso, ganha especial relevância o fato de muitos produtos, anteriormente restritos ao país de origem, passarem a ser disponibilizados em terras distantes (ROCHA; RIAL, 2014, p. 3).

\footnotetext{
${ }^{1}$ É Doutor em Ciências e Pós-doutor em Antropologia da Alimentação, na linha de pesquisa Patrimônio Alimentar e Turismo, pelo Observatorio de la Alimentación, na Universidad de Barcelona. É pesquisador colaborador do Observatorio de la Alimentación (Odela/Universidad de Barcelona), pesquisador membro do Laboratório de Políticas Culturais e Ambientais do Brasil (LApCAB/UNISINOS) e pesquisador membro do Alere, Grupo de Pesquisa em História da Alimentação e Abastecimento na Amazônia/CNPq. Desenvolve pesquisas nos campos da Antropologia Visual e da Antropologia da Alimentação, em particular da comida como patrimônio alimentar do nordeste paraense. E-mail: micanbri2013@gmail.com.
} 
As arguições sobre os fluxos alimentares numa perspectiva global, quase sempre, senão sempre, são construídas a partir dos movimentos migratórios de pessoas. Dito de outro modo, o deslocamento de alimentos vinculado ao fluxo migratório das pessoas constitui a base para compreender-se tanto a expansão da história global, quanto os diferentes sistemas alimentares inventados e reinventados por meio de trocas culinárias no decorrer desses movimentos (PICANÇO, 2018). Portanto, a alimentação, vinculada às migrações, é " [...] parte constitutiva da história humana" (ROCHA; RIAL, 2014, p. 4).

Sendo assim, considera-se que as coisas alusivas ao ato de comer têm desempenhado papel decisivo para a expansão e corroboração da história global, uma vez que os produtos alimentícios foram os primeiros dentre os demais a serem comercializados em termos globais. Isso resultou na aproximação e nos intercâmbios de culturas, desde uma perspectiva alimentar. Com isso, pode-se considerar que nenhuma outra dimensão da vida foi tão profícua em termos globais quanto às dimensões enredadas com o ato de comer. Isso decorre do fato de a alimentação humana ter lugar privilegiado de interligação. "[...] entre pessoas, lugares e contextos culturais" (ROCHA; RIAL, 2014, p. 3).

Assim, este paper discorre sobre os movimentos migratórios e suas implicações nos novos e antigos modos de comer, considerando as experiências e as práticas de acesso ao alimento, de sociabilidades e comensalidades empreendidas por imigrantes brasileiros e paraenses no território catalão, particularmente em Barcelona.

Este artigo está estruturado em duas seções. Na primeira, descrevo por meio de narrativas textuais e imagéticas os lugares onde os imigrantes acessam os alimentos de origem brasileira, ou não, para posterior feitura de suas comidas, assim como aponto algumas experiências vivificadas por esses imigrantes em outros lugares onde as comidas são dispostas prontas para degustação. Falo dos restaurantes, principalmente aqueles que povoam as rotas turísticas de Barcelona. Na segunda seção, as descrições e análises são elaboradas a partir de observações, às vezes, participantes, de conversas formais e informais obtidas durante experiências dos e com os imigrantes em relação à cozinha brasileira e paraense, agora não mais nos mercados, mas em suas casas, em suas cozinhas, em suas mesas.

Dito isso, importa frisar aqui que este artigo se inscreve no âmbito do meu Pósdoutorado em Antropologia da Alimentação, na linha de pesquisa: Alimentação, patrimônio e turismo, levado a cabo de julho de 2018 a janeiro de 2019, no Observatorio de la Alimentação, na Universidade de Barcelona. Também é necessário registrar que o trabalho de campo teve início no ano de 2017, no período em que estive em Barcelona cursando o Doutorado Sanduíche (PDSE/CAPES).

\section{SOBRE OS LUGARES ONDE COMPRAM E COMEM OS IMIGRANTES BRASILEIROS E PARAENSES EM CATALUNHA}

Inicio esta seção pontuando que faz tempo que a cozinha brasileira e a paraense transpuseram o Atlântico e se presentificaram no mercado Catalão, povoando ora as prateleiras dos supermercados, das tabernas, dos sites, dos açougues, dos restaurantes e ora as mesas dos mais de 37.691 imigrantes brasileiros que habitam em Catalunha, pois, conforme dados do Ministério das Relações Exteriores (2015), a Espanha é o sexto país com maior concentração de imigrantes brasileiros. O mais amplo contingente reside nas cidades de Madri, com 49 mil imigrantes, totalizando 86.691 brasileiros vivendo legalmente naquele país, afora aqueles que ali habitam informalmente.

Estes últimos, assim como os outros, atravessaram meu fazer antropológico durante esta empreitada - suas vozes estão registradas em algum lugar das páginas deste artigo - que teve início no ano de 2017, quando estive no Observatorio de la Alimentacíón, para uma 
instância doutoral, no âmbito do PDSE, cuja continuidade se deu no segundo semestre do ano de 2018, desta vez, no âmbito do meu Pós-doutorado.

Minhas incursões em campo no ano de 2017 me permitiram notar, dentre outras coisas, que os alimentos brasileiros estão dispostos nos mercados de Barcelona de modo diversificado, por exemplo, arroz e feijão (mesmo não sendo de origem brasileira) são facilmente encontrados nas grandes redes de supermercado, o mesmo ocorrendo com a mandioca. Já outros são dispostos nas prateleiras dos açougues, das tabernas e das lojas afrolatinas, que são facilmente encontradas pelo território catalão, inclusive elas se fazem notar em lugares centrais de Barcelona, como a Avenida Via Laietana, considerada zona turística da cidade, conforme mostra a imagem 1.

Nessas lojas são encontrados inúmeros produtos alimentícios de origem brasileira, tais como: arroz, feijão, café, temperos, condimentos, enlatados, embutidos, etc.

Imagem 1 - Loja Afro-latina

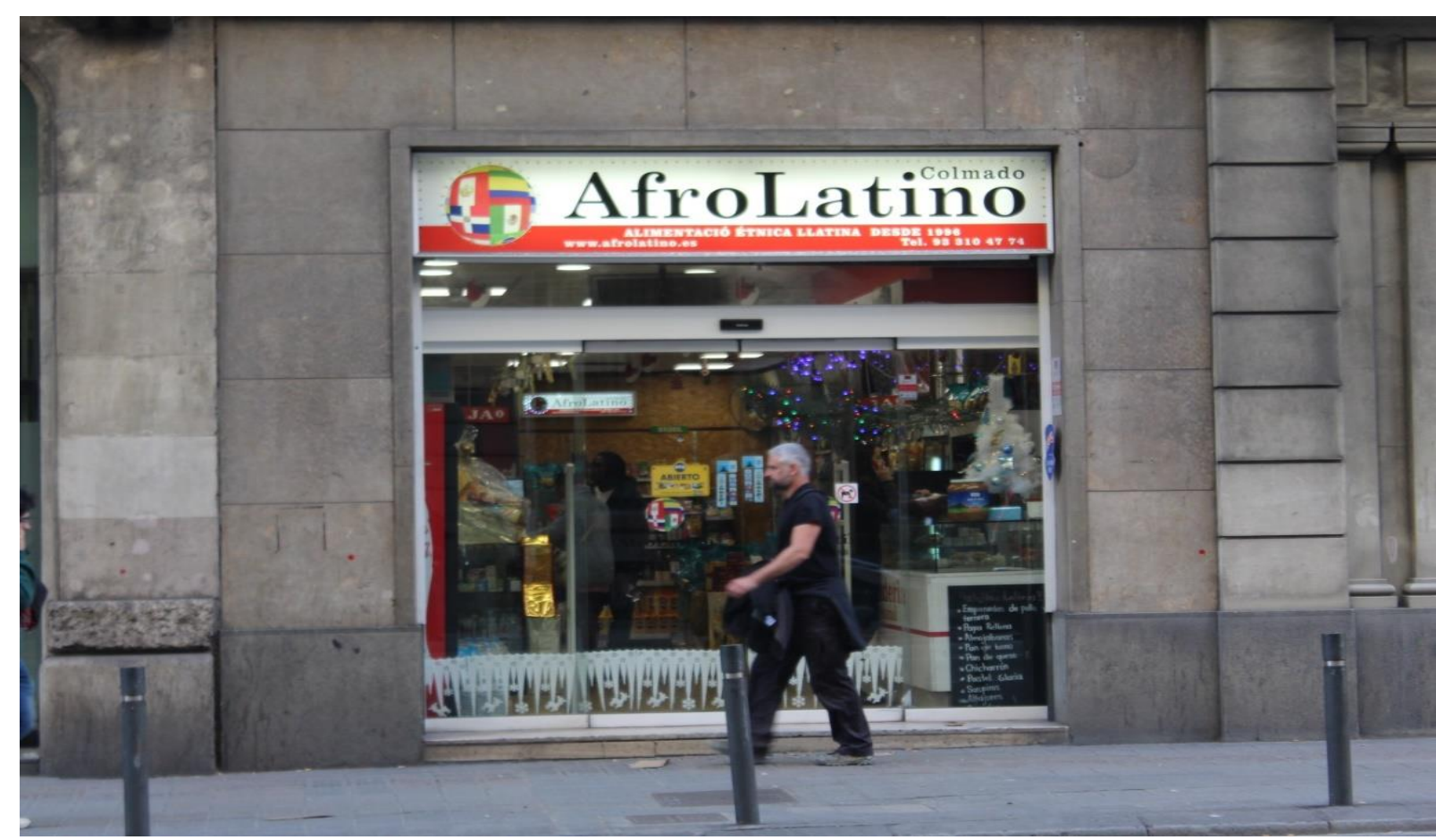

Fonte: arquivo do autor, 2018.

Dentre eles, estão alguns que dizem muito da cozinha paraense, a saber, a mandioca e seus derivados, tais como goma para tapioca, farinha de tapioca, macaxeira in natura, farofa, carimã e farinha de mesa. "Esta última é disposta em sacas e vendida a granel, assim como fazem os paraenses em suas barracas de farinhas nas feiras das cidades do estado do Pará. [...]. (PICANÇO, 2017, p. 214), conforme mostra a imagem 2. 
Imagem 2 - Farinha a granel

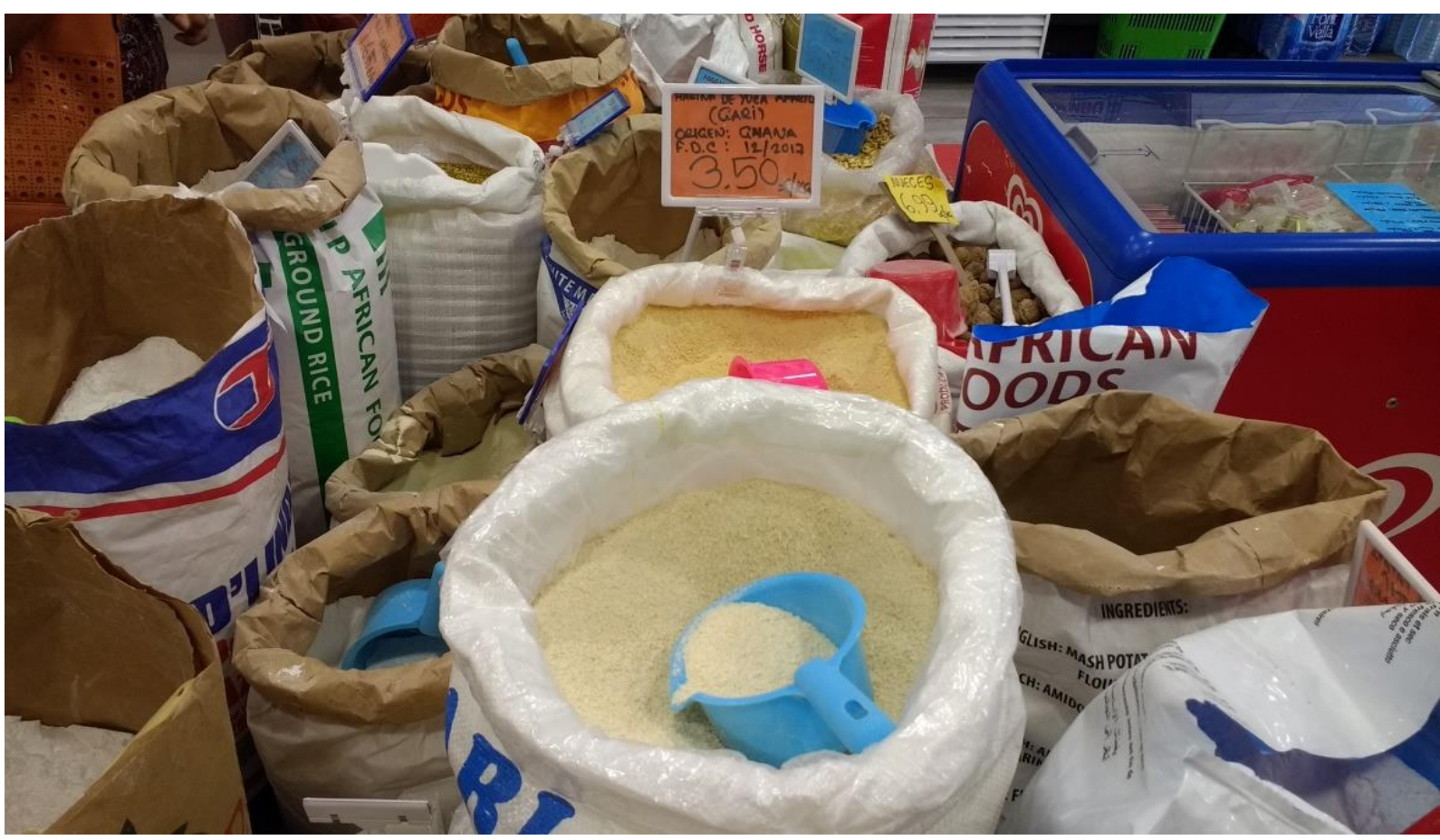

Fonte: arquivo do autor, 2017.

Além das lojas físicas, os imigrantes também contam com a venda dos já citados e de outros produtos alimentícios brasileiros, como, por exemplo, as verduras e legumes, como couve, quiabo, etc., além das pamonhas, conforme me relatou Larysse Farias, que é paraense e vive em Barcelona faz 15 anos.

Às vezes eu compro nas lojas dos paquistaneses e dos marroquinos, que vendem muita comida do Brasil. Outras coisas eu compro pela internet. Por exemplo, tem uma página no facebook que é de uma horta brasileira e eles vendem uma infinidade de coisas do Brasil. Por exemplo, eu sempre compro dessa horta pamonha, couve, quiabo e outras coisas. A gente pede e chega rapidinho (Entrevista concedida em 25 de outubro de 2018).

Além disso, os brasileiros e paraenses podem recorrer a La Boqueria (imagem 3), considerado o mercado mais famoso e quiçá mais turístico de Barcelona, localizado na Rambla de Sant Josep, mais conhecida como Rambla de Barcelona. 


\section{Imagem 3 - La Boqueria}

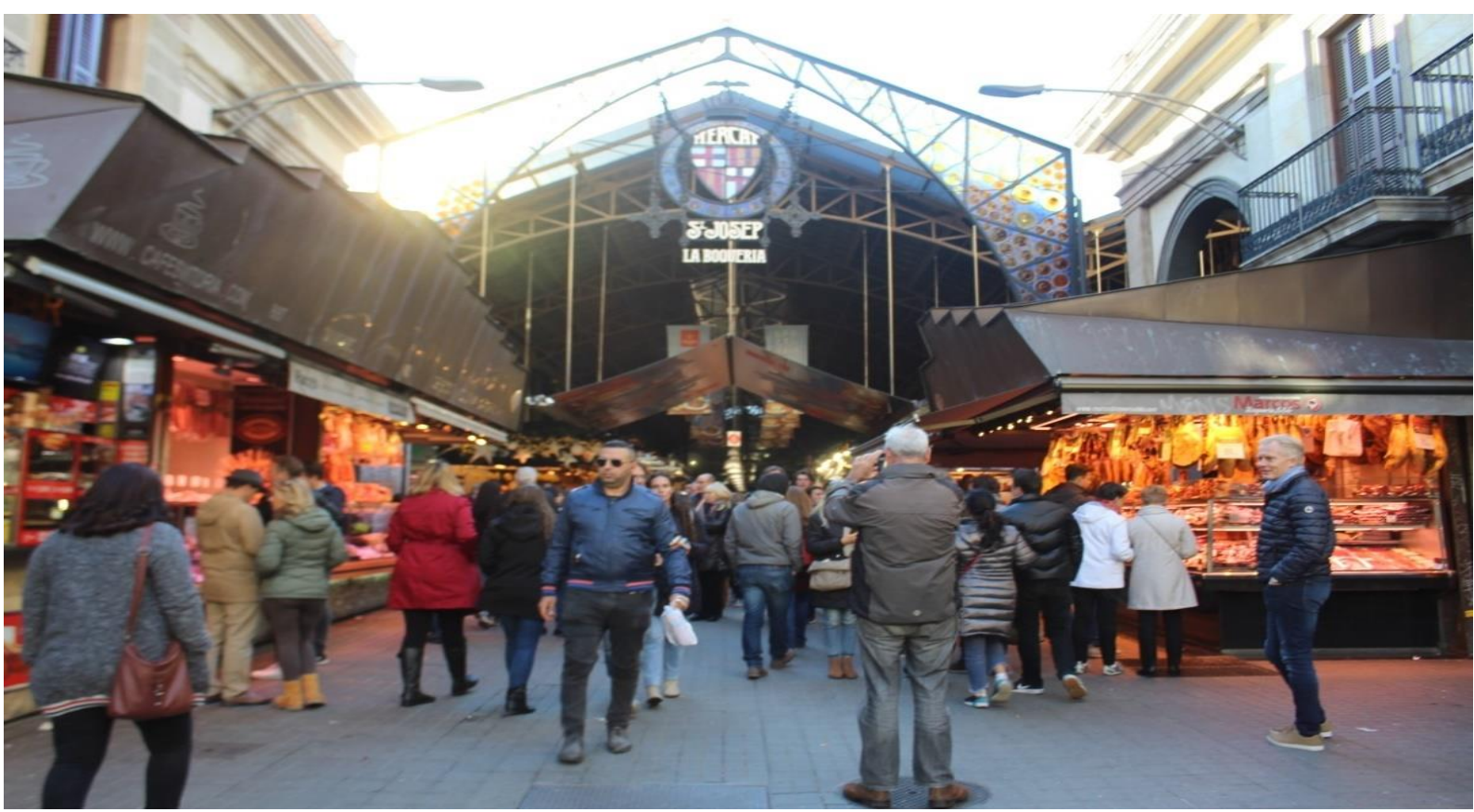

Fonte: arquivo do autor, 2018.

Afora isso, ao La Boqueria é atribuída a fama de mercado cosmopolita. Nele, os visitantes, além de conhecerem, degustarem e encontrarem alimentos da cozinha nativa da Catalunha, também experimentam uma infinidade de sabores das mais variadas cozinhas do planeta, inclusive do Brasil e do Pará, pois as lojas de alimentos latinas, conforme mostra a imagem 4, ajudam no adensamento da qualidade cosmopolita atribuída ao mercado, quando elas ali comercializam uma leva significativa de alimentos de origem brasileira, ou não. Estes, em alguns lugares do Brasil, como no estado do Pará, são, segundo Picanço (2018), apontados como patrimônio alimentar do lugar, tais como a pupunha, o cupuaçu, a farinha de mandioca e a goma para tapioca.

Imagem 4 - Loja latina em La Boqueria

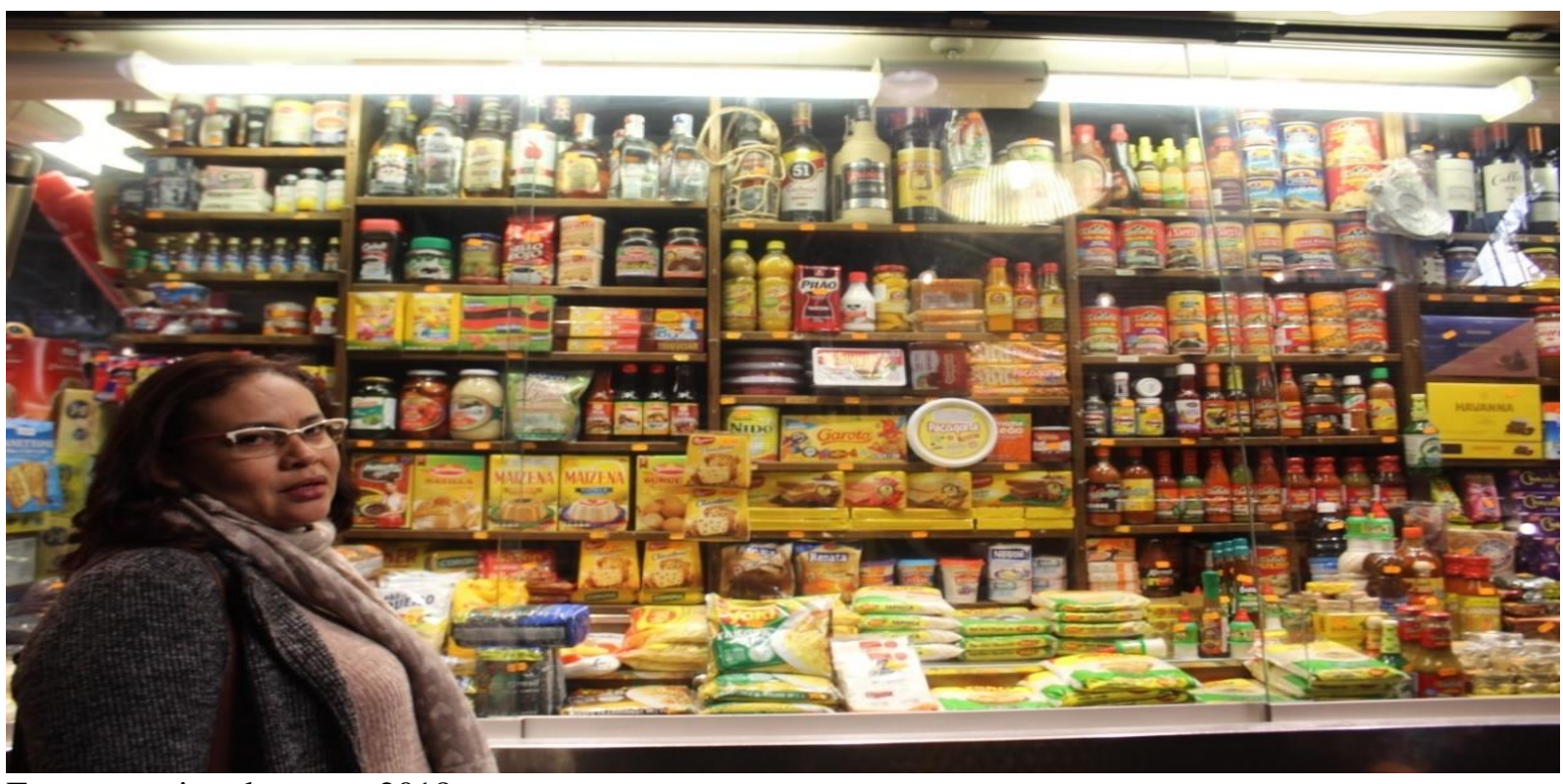

Fonte: arquivo do autor, 2018. 
Nos lugares até aqui mencionados, os brasileiros e paraenses podem acessar produtos alimentícios para fazerem suas comidas, porém existem outros lugares em Catalunha onde os alimentos já lhes esperam prontos para serem degustados.

Imagens 5 a 7 - Brasa Rio e os sabores brasileiros e paraenses

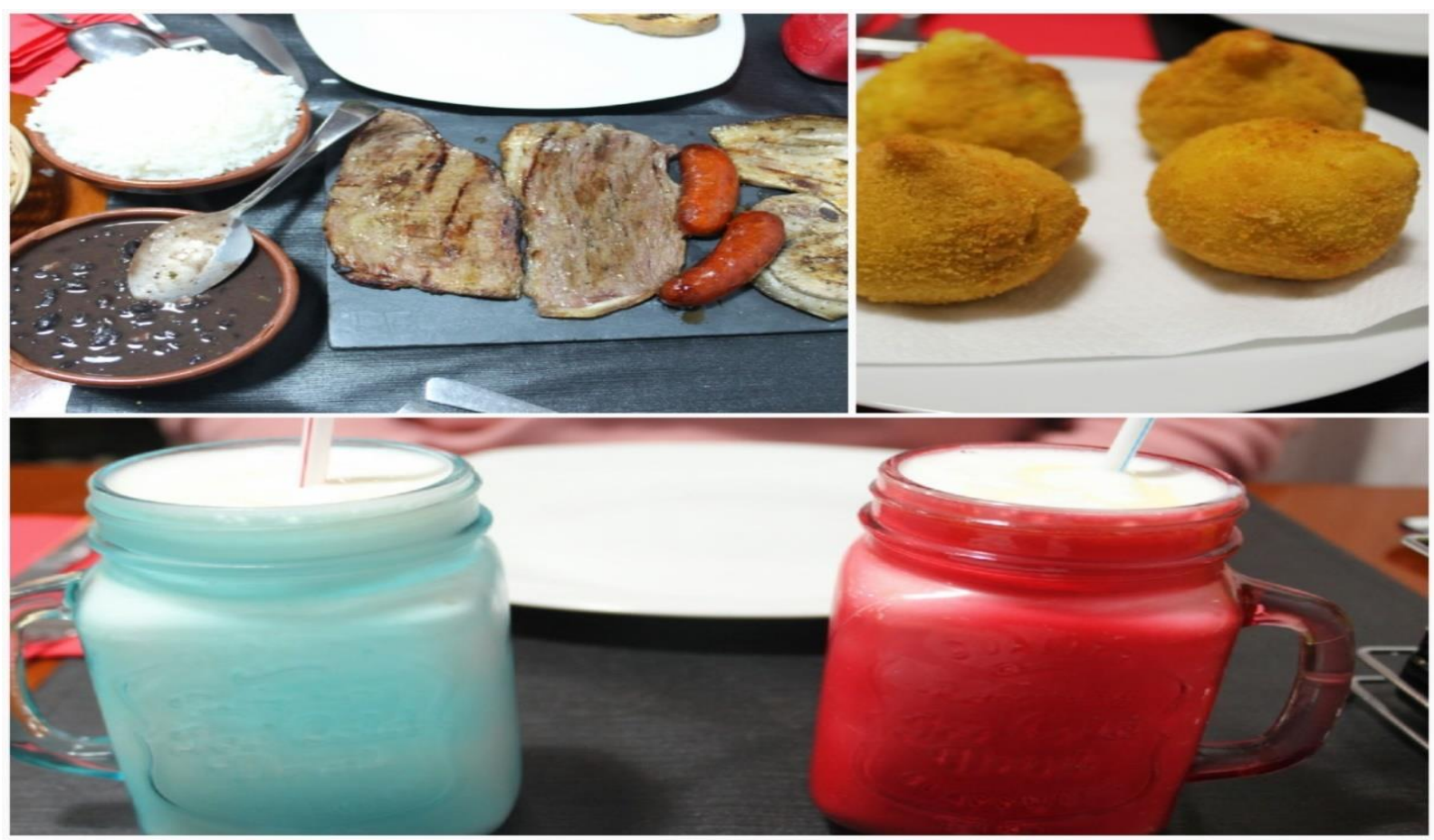

Fonte: arquivo do autor, 2018.

Falo dos restaurantes brasileiros que povoam aquele território, dentre os quais cito o Brasa Rio, situado em Santa Coloma de Gramenet. No cardápio, além da feijoada, os clientes também podem degustar, dentre outros sabores, o churrasco de picanha com arroz e feijão à brasileira com farofa e de sobremesa as tão apreciadas coxinhas. Além disso, para os brasileiros paraenses, o restaurante disponibiliza apetitosos sucos de cupuaçu (imagens 5, 6 e 7).

Ademais, o churrasco brasileiro pode ser degustado em outros lugares especializados no assunto, como na Churrascaria Brasileira, que está localizada no shopping Splauem em Cornellà de Llobregat. A demanda pelo churrasco brasileiro é tanta, que os brasileiros, os catalães e outros aguardam em filas, conforme imagens 8, 9 e 10, para degustá-lo. De fato, essa churrascaria é uma franquia da marca Churrascaria Brasayleña e povoa outros shoppings de Barcelona. 


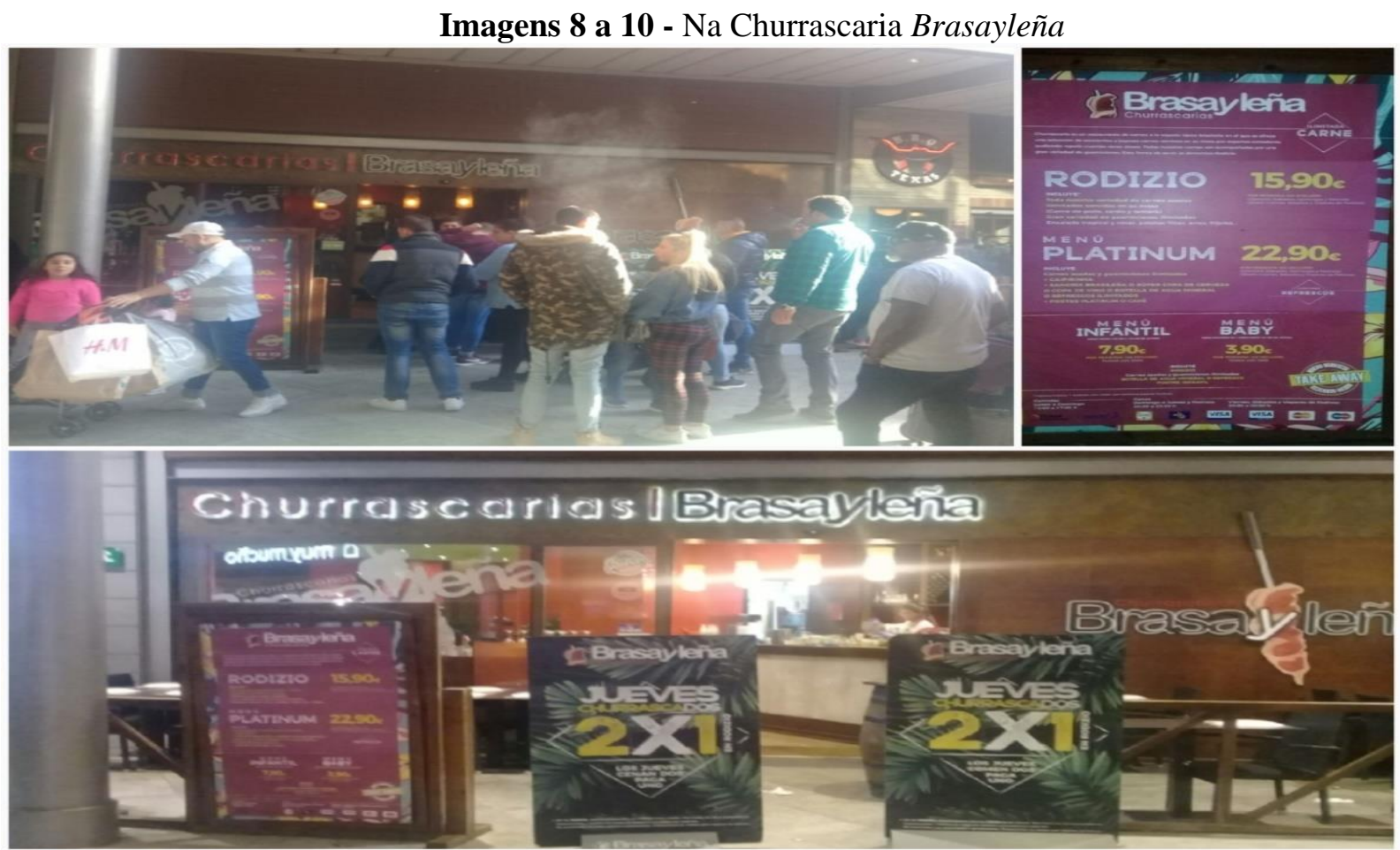

Fonte: arquivo do autor.

Importa ressaltar que tanto o Brasa Rio quanto a Churrascaria Brasayleña, são espaços gastronômicos situados à margem da rota turística de Barcelona, diferentemente daqueles que estão sediados no "coração" daquela cidade, como é o caso do La Carioca, conforme mostra a imagem 11, localizado exatamente na zona turística do lugar.

O La Carioca encontra-se situado na Plaça de Pau Vila, centro de Barcelona. É um lugar requintado, com práticas alinhadas à indústria turística com discursos que enfatizam que ali se tem a melhor, a mais tradicional comida brasileira. No cardápio, uma variedade de pratos, dentre os quais: a feijoada, o feijão, o arroz, o churrasco e bebidas, como a caipirinha.

Além desses, no referido restaurante, se pode também degustar a tapioca e o açaí. Pelo que observei, estas duas últimas comidas são os pratos considerados os "carros-chefe" do La Carioca, ao menos era o que indicava nos banners de propagandas dispostas em frente ao restaurante, cujos destaques eram para a tapioca e suas benesses, como a sua suposta ausência de glúten, assim como para o açaí, que, segundo o encarte, é rico em proteínas, nutrientes e antioxidantes, conforme indica a imagem 12. 


\section{Imagem 11 - La Carioca}

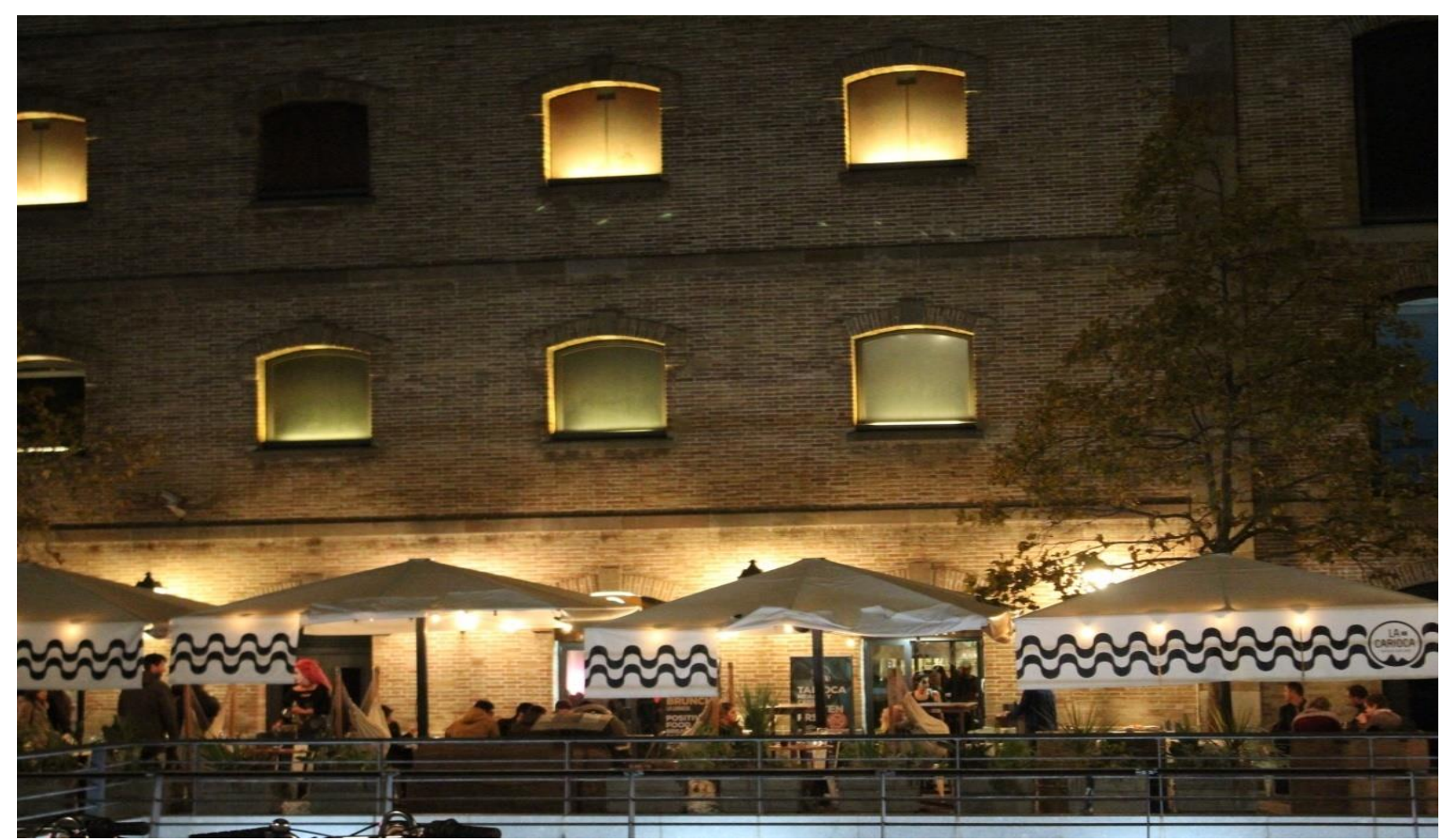

Fonte: arquivo do autor, 2018.

Imagem 12 - Tapioca e Açaí, cardápios principais do La Carioca

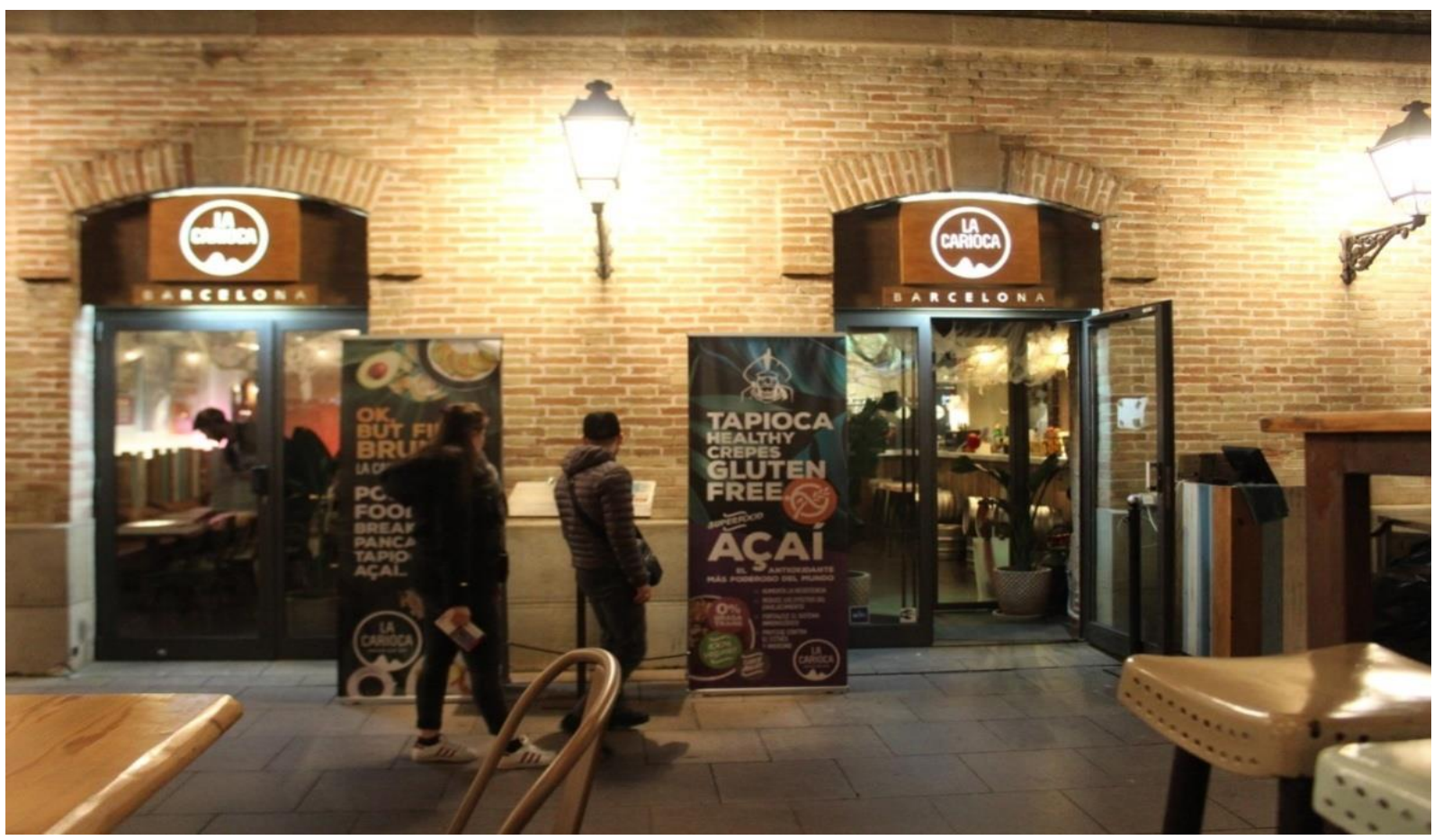

Fonte: arquivo do autor, 2018.

As comidas em destaque na mencionada placa me chamaram a atenção pelo fato de tanto a tapioca quanto o açaí estarem ali, sendo comercializados e degustados na condição de comida nacional, pois conforme sinalizado por Cascudo (2011) e Picanço (2018), tanto um 
quanto o outro, em termos de Brasil, estão mais para comidas regionais (Norte e Nordeste) do que para comida nacional.

O açaí, por exemplo, é uma das mais importantes comidas da mesa dos paraenses, de norte a sul daquele estado. Na capital Belém, o fruto constitui-se em alimento diário, em prato principal da mesa daquela gente. Com a tapioca não é diferente, lá ela também se manifesta como comida do dia a dia seja no café da manhã, ou no café da tarde. A iguaria pronta para o consumo pode ser encontrada com facilidade pelas barracas espalhadas pelas ruas de Belém, assim como pelos tabuleiros dos tapioqueiros que as vendem todas as tardes, pelas ruas da capital paraense.

Portanto, parece que a tapioca e o açaí são dois pratos considerados comidas tradicionais do Pará e de outros estados do Norte e do Nordeste brasileiro e, por serem assim, não povoam com regularidade as mesas dos cariocas. Assim, não seria descabido apontar que estamos diante de um processo que tenta nacionalizar os patrimônios alimentares que historicamente têm funcionado como marcadores das identidades coletivas do Norte e quiçá do Nordeste do Brasil.

Segundo Picanço (2018), a tentativa de nacionalizar a tapioca se deu quando nutricionistas descobriram nela a ausência de glúten. Isso teria então provocado o deslocamento do seu consumo do eixo norte-nordeste para as demais regiões brasileiras. Caso parecido ocorreu com o açaí, que, por ser provido de propriedades energéticas, passou a nutrir esportistas ou não em todas as partes do Brasil, onde é consumido como bebida energética, enquanto que no Pará ele continua sendo comida.

Ademais, as tapiocas do La Carioca, - que são mais de dez modalidades recheadas de carne seca, picanha, queijo, carne de frango, mortadela, etc. - são incorporados elementos que normalmente não estão presentes nas tapiocas comidas no dia a dia dos belenenses, pois lá, elas são tradicionalmente feitas de duas maneiras: as enxutas e/ou salgadas, que depois de prontas são levemente encharcadas com margarina ou manteiga, e as molhadas e/ou doces, que são encharcadas com leite de coco e leite condensado e recheadas com coco ralado. Tanto uma quanto a outra são, quase sempre, degustadas acompanhadas de café.

Afora isso, no La Carioca, outros elementos são agregados à iguaria, tais como o cesto, a bandeira brasileira e o encarte com a imagem do Cristo Redentor, conforme mostrado na imagem 13. O conjunto dessas incorporações ao mesmo tempo em que torna a iguaria gourmetizada, funciona como recurso a memória que potencializa uma das competências inerentes à comida, a saber, a capacidade de aguçar as memórias afetivas e gustativas das pessoas, no caso aqui tratado, dos imigrantes brasileiros e paraenses, pois tais detalhes remetem a lembranças do lugar de origem, da casa, da família. 
Imagem 13 - Tapioca gourmetizada no La Carioca

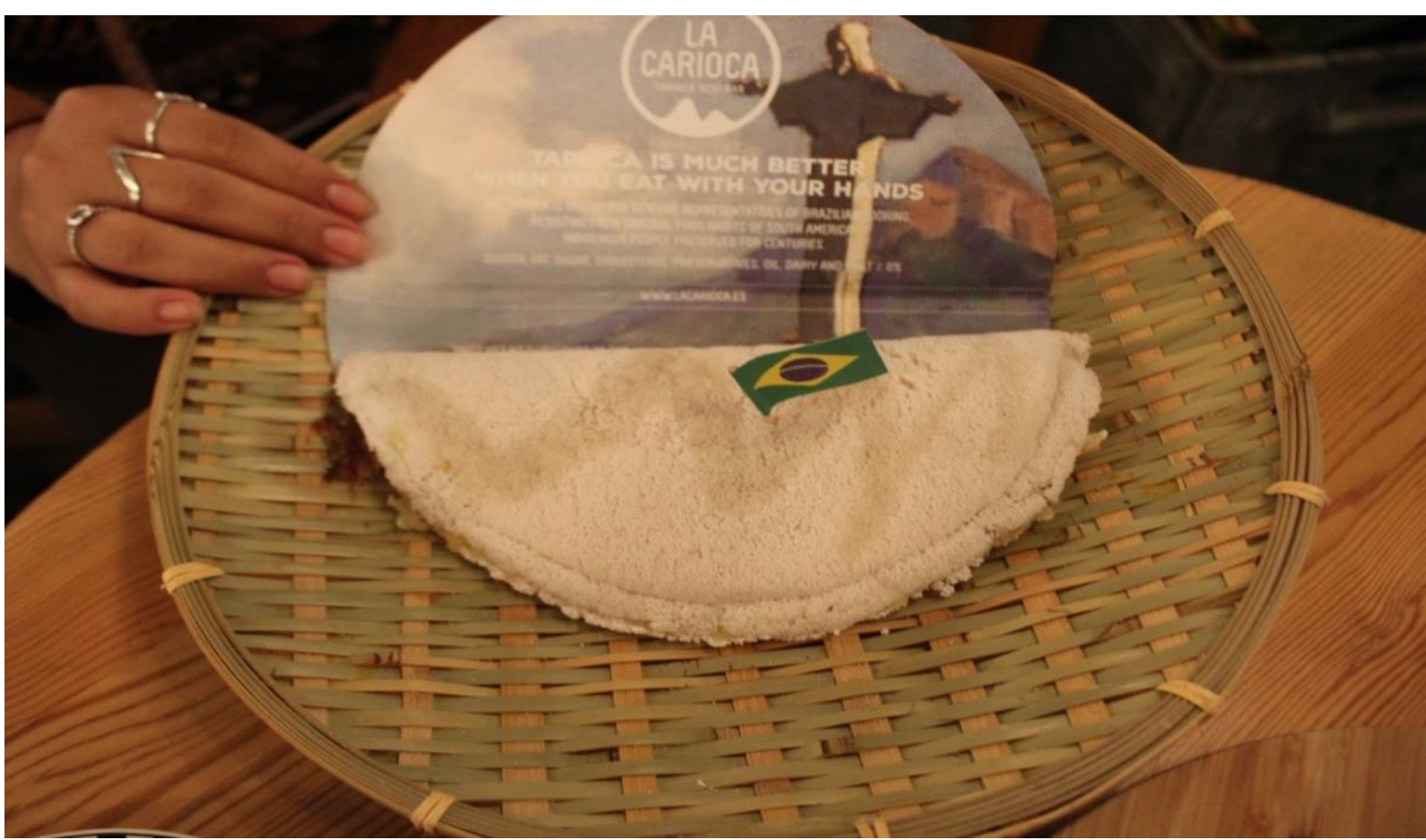

Fonte: arquivo do autor, 2018.

Outrossim, argumenta-se aqui que esses elementos são estrategicamente incorporados à tapioca e se inscrevem em práticas que dialogam com os pressupostos da indústria turística, cuja finalidade é tornar as coisas vendáveis, inclusive aquelas tidas como patrimônio cultural, dentre as quais se incluem os patrimônios alimentares. Tais incorporações possibilitam a reinvenção da tradição, compreendidas como releituras, necessárias para que a coisa continue como tradição (SERRA, 2014).

Nesse processo, segundo Prats (2006) e Serra (2014), o turismo funcionaria com lugar privilegiado para a continuidade da tradição. Isso é notório no caso do La Carioca, que dispõe no epicentro de seu discurso e de suas práticas a ideia de que ali se tem a melhor, a mais tradicional comida brasileira em Barcelona, tratando-se, portanto, de "[...] estrategia que contribuye a legitimar el patrimônio cultral y los atractivos de uma localidad através de discursos y prácticas culturales y turisticas." (WINTER, 2013, p. 788). Ou seja, alguns bens, tidos como patrimônios culturais, assim permanecem na medida em que a indústria do turismo e do entretenimento os dispõe como mercadorias comercializáveis (mesmo que como coisas híbridas, mais ou menos próximas daquilo que um dia elas foram, ou daquilo que elas ainda são em seu contexto primeiro) em eventos e lugares estratégicos dispostos pelas mais diversas cidades do mundo. (PRATS, 2006; SERRA, 2014).

Portanto, segundo Prats (2006) e Serra (2014), ao se manifestarem em contextos turísticos, as coisas, inclusive as comidas, reproduzidas se mostram recursivamente capazes de garantir a continuidade da tradição, ao mesmo tempo que se fazem próprias ao consumo, assegurando-lhes a condição, no caso da tapioca, de patrimônio alimentar de brasileiros e paraenses.

Dito isso, a partir da próxima seção tratarei de outras experiências dos emigrantes com a comida brasileira e paraense, agora em outros lugares, a saber, em suas casas e com os amigos, conforme descrevo no que segue. 


\section{ESTRATÉGIAS E EXPERIÊNCIAS DE COMENSALIDADES PARA ALÉM DOS MERCADOS E DO TURISMO}

As comidas vendidas nesses lugares não têm o mesmo gosto da comida brasileira. Por mais que eles ponham temperos e se esforcem, não adianta, fica parecido, mas não é a mesma coisa (Fernanda Calandrini, entrevista em 15 de dezembro de 2018).

A epígrafe acima refere-se ao descontentamento de Fernanda Calandrini natural de Viseu, no estado do Pará, e que vive em Barcelona faz 15 anos, em relação ao sabor das comidas comercializadas nos estabelecimentos citados na seção anterior. Assim como ela, todos os demais brasileiros com quem dialoguei comungam da mesma percepção: a comida brasileira vendida nesses lugares de Barcelona não tem o mesmo sabor, "na verdade a gente come uma ideia da comida brasileira, mas é o que tem" (Maria Clara, em entrevista, em 5 de dezembro de 2018).

Além da insatisfação no tocante ao sabor, para alguns, a comida parece ser desprovida de sustança, ao menos para Getro, que é natural de Ribeirão Cascalheira, Mato Grosso e está em Barcelona faz dois anos. "A comida daqui é sem gosto e parece que não sustenta a gente. Quando eu cheguei aqui, eu comia toda hora e parecia que não tinha comido nada. Ainda hoje, dois anos depois, continua não me enchendo" (Getro, em entrevista concedida em 20 de novembro de 2018).

Afora isso, outros estranhamentos dos imigrantes dizem respeito à composição do prato e aos horários das refeições. Diferentemente do Brasil, em Barcelona o cardápio segue outra estrutura, a saber: primeiro, serve-se a entrada, que pode ser uma salada mediterrânea: verduras e legumes como esparragos, azeitonas, atum e ovos, mas também pode ser lentilhas com toicinho de jamón e chouriço, por exemplo, depois, serve-se o prato principal, que normalmente é à base de carne de peixe, de frango, de porco ou de boi, e em seguida é servida a sobremesa: uma fruta, um creme, um doce, etc, (conforme mostram as imagens 14 a 17). Tudo isso entremeado pelo pão, que ocupa centralidade na composição alimentar do povo Catalão, o qual costuma finalizar as refeições consumindo o pão encharcado nas sobras do molho que fica no prato, conforme mostrado na imagem 18.

Ademais, os horários das refeições dos brasileiros e catalães também são marcados por diferenças, pois enquanto no Brasil, de modo geral, se almoça às $12 \mathrm{~h}$, em Catalunha, particularmente em Barcelona, se come a partir das 14h e se janta entre 21 e $22 \mathrm{~h}$. Alguns dos meus interlocutores disseram estarem adaptados à estrutura e à composição da cozinha catalã, outros nem tanto, e na tentativa de amenizar os conflitos e as diferenças culinárias, seja entre os gostos, os horários ou a estrutura do cardápio, eles empreendem algumas estratégias e experiências de comensalidades, que descreverei no que segue.

Durante minha estada em Barcelona no ano de 2017, conheci Cynara Blanco, de 44 anos, natural da cidade de Bragança, do estado do Pará e que vive em Barcelona desde o ano de 2003. Cynara se diz adaptada ao lugar, porém não se desprendeu de algumas coisas de sua terra natal, em especial do sabor da comida que compunha seu paladar de outrora: "sinto muita saudade da comida da minha terra" (Cynara Blanco, em entrevista concedida em 25 de maio de 2017) e para amenizar tal saudade ela costuma cozinhar e oferecer almoços paraenses.

Sempre que posso faço um almoço, principalmente em datas especiais, comemorativas e convido meus amigos paraenses que moram aqui, convido outros brasileiros de outras partes do Brasil e também convido meus amigos espanhóis e sempre sirvo essas comidas típicas do Pará (Cynara Blanco, em entrevista concedida em 25 de maio de 2017). 
Imagens 14 a 17 - Estrutura alimentar básica em Barcelona

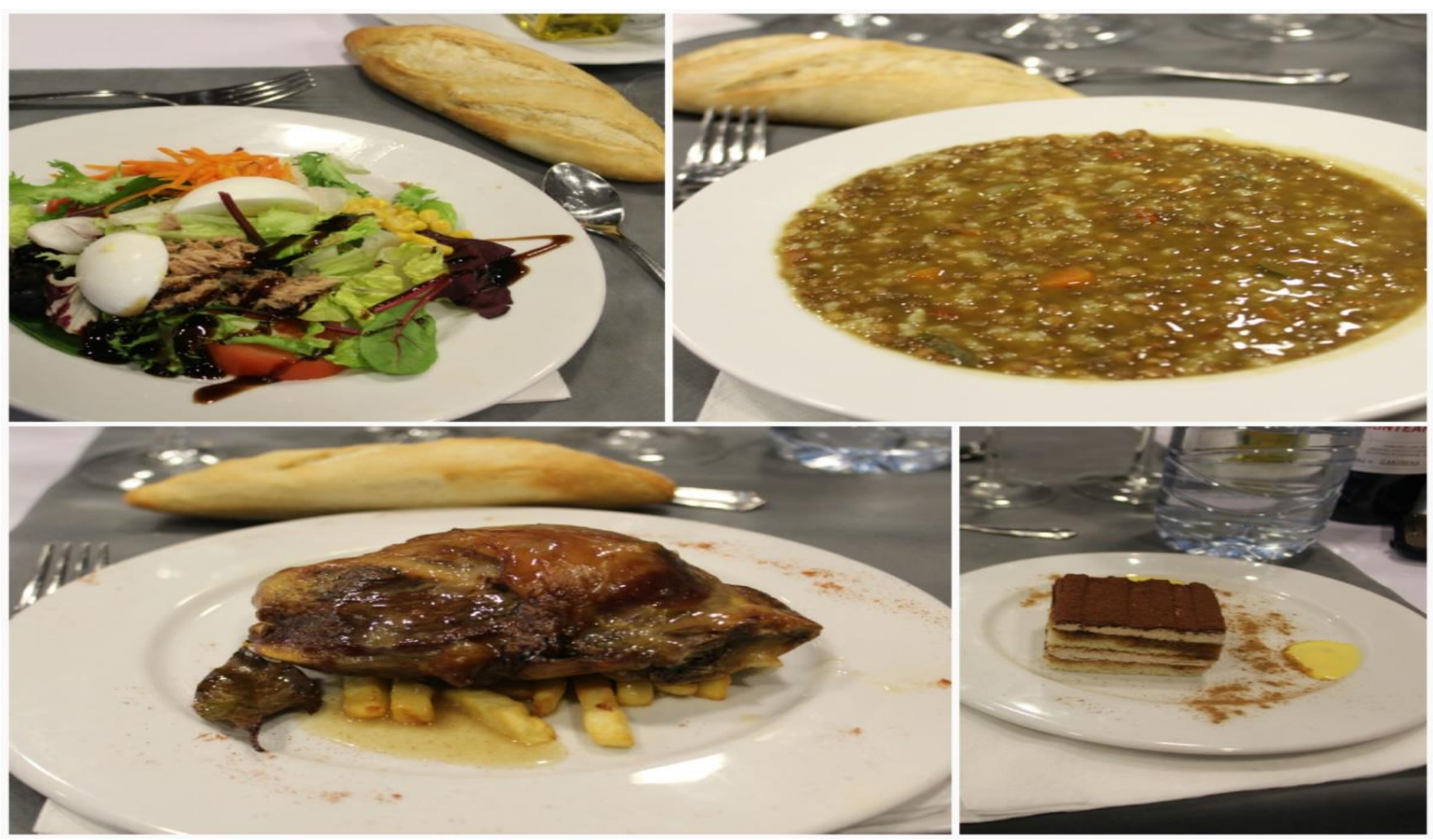

Fonte: arquivo do autor, 2018.

A convite de Cynara, testemunhei dois almoços em sua casa. O primeiro ocorreu no dia 21 de outubro e lá estavam, além da anfitriã, Fernanda Calandrini, com sua filha e sua neta, e Paula Monteiro, que é paraense, da cidade de Bragança. No cardápio, uma caldeirada de peixe acompanhada de pimenta na salga, farinha d'água e açaí, ambos de origem bragantina. $\mathrm{O}$ segundo almoço se deu no dia $1^{\circ}$ de dezembro, por ocasião do aniversário de Cynara, conforme mostram as imagens 19 a 23, que foi regado a pato no tucupi, maniçoba e farinha d'água, trazidos de Bragança nas malas de Cynara, em sua última viagem ao Brasil, em setembro de 2018.

Imagem 18 - O pão nas sobras do prato

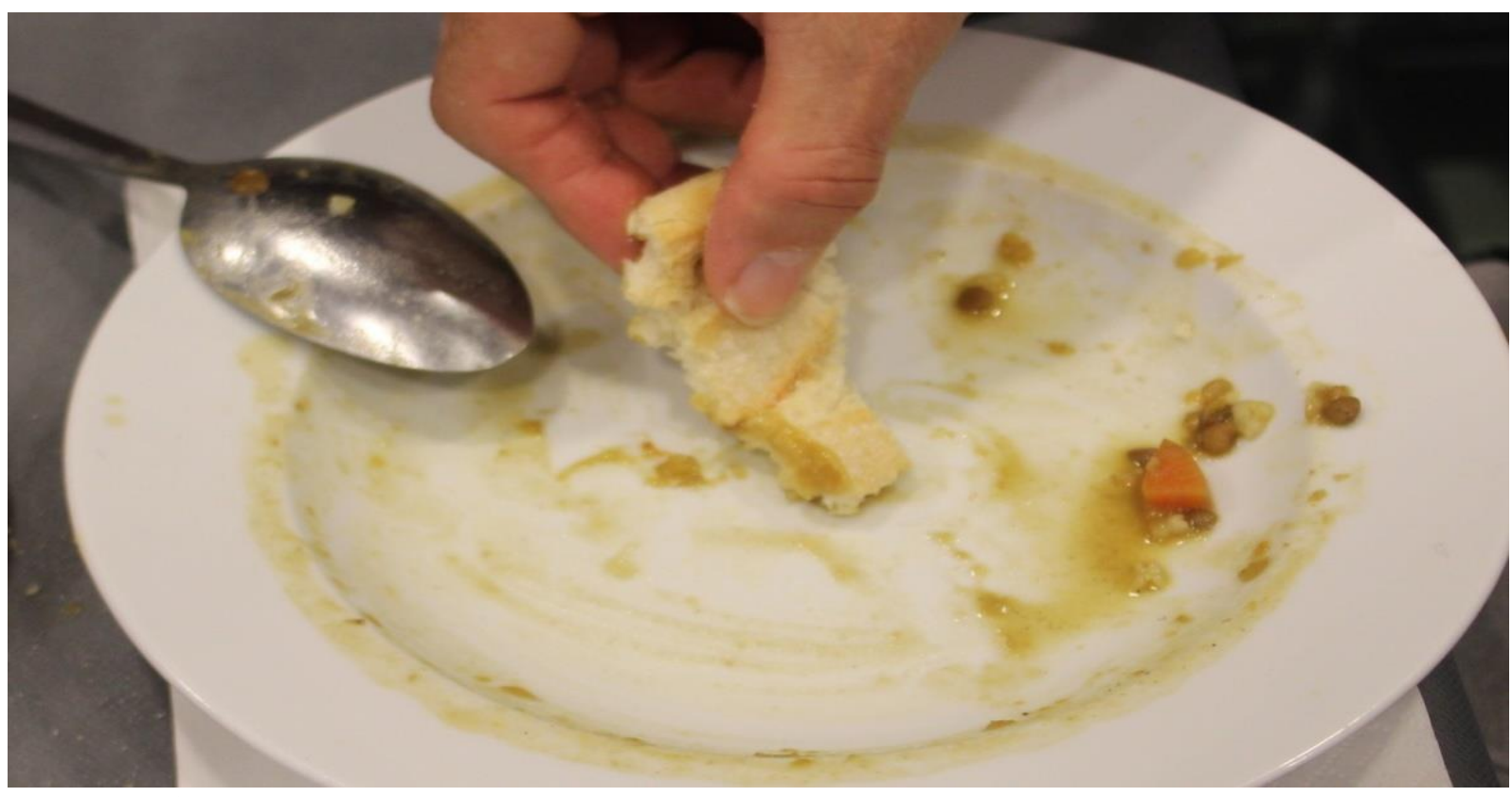

Fonte: arquivo do autor, 2018. 
Desta última vez, entre os convidados, estavam brasileiros de quase todas as regiões do país, além de espanhóis, salvadorenhos e José, que é de origem boliviana com nacionalidade francesa e é casado há nove anos com Isis, a qual é do Mato Grosso e vive em Barcelona faz 14 anos.

Imagens 19 a 23 - Almoço paraense em Barcelona

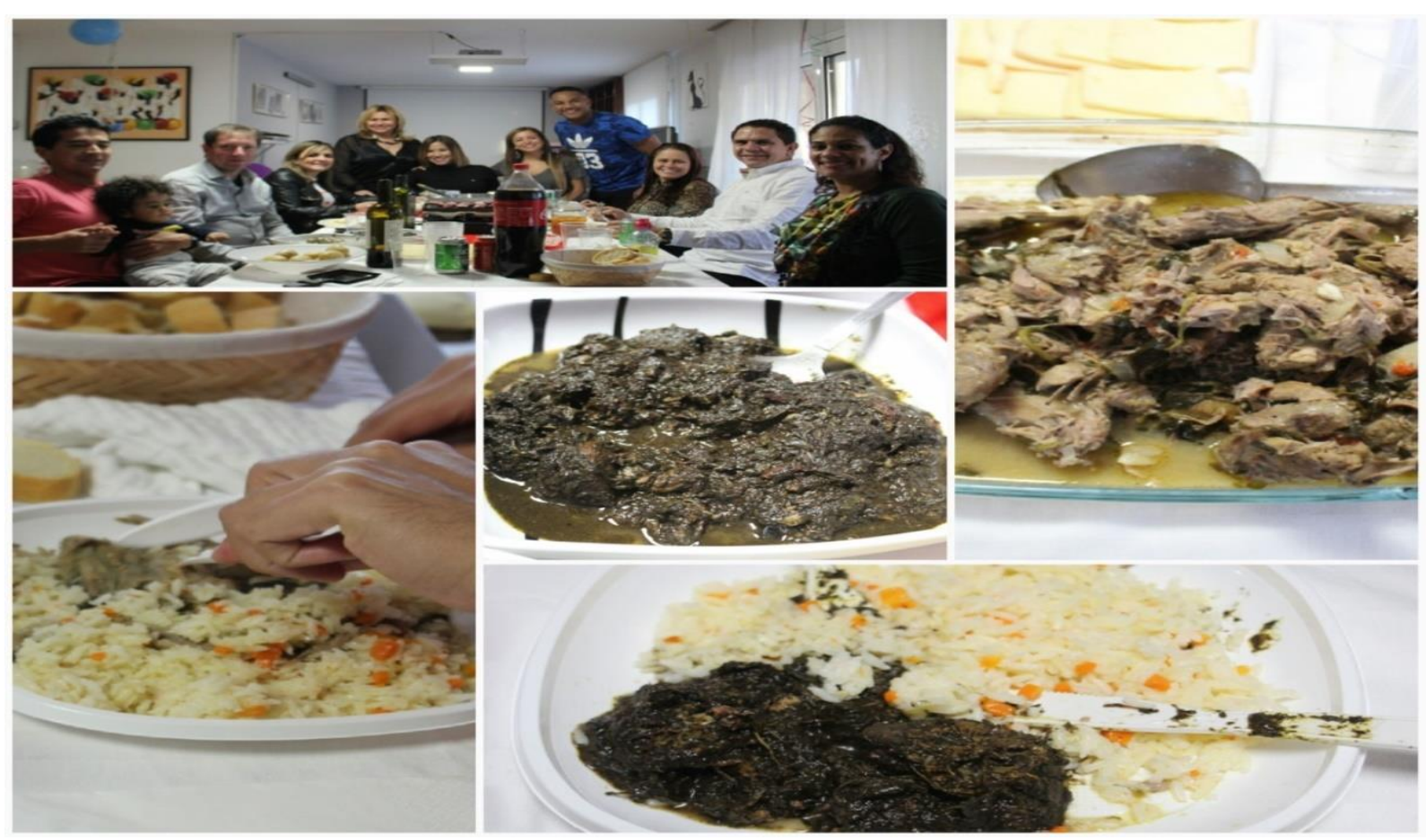

Fonte: arquivo do autor, 2018.

Isis me relatou que, apesar de estar acostumada com a cozinha catalã, em sua casa não falta comida brasileira, especialmente feijão e arroz, além da pimenta malagueta na salga ao óleo e da farofa de farinha de mandioca com ovos. Em algumas ocasiões especiais, ou nos finais de semana, Isis costuma fazer feijoada, churrasco de picanha e vinagrete. Suas experiências culinárias têm sido provadas e aprovadas por seu esposo José: "Me encanta la comida brasileña, me gusta mucho de la barbacoa de picanha, me encanta la farofa de harina de mandioca con huevo, la vinagreta y la pimienta malagueta" (José, em entrevista concedida em $1^{\circ}$ de dezembro de 2018).

Próximas às práticas comensais levadas a cabo por Cynara são as empreendidas por Maria Clara, de 33 anos, brasileira de São Paulo, que vive entre França e Barcelona faz 11 anos. Atualmente é professora associada do Campus de La Alimentación, da Universidad de Barcelona, onde ministra a disciplina Antropologia da Alimentação. Maria Clara se diz adaptada à cozinha catalã, mas, mesmo assim, o arroz povoa sua mesa ao menos duas vezes na semana. "Tem alguns produtos brasileiros que eu como, ou quando bate a saudade de casa, como o pão de queijo, a coxinha, o brigadeiro, a feijoada, a moqueca, o camarão na moranga, a tapioca." (Maria Clara, em entrevista em 5 de dezembro de 2018). Afora isso, em ocasiões especiais ela convida os amigos brasileiros e estrangeiros para comer em sua casa. Também costuma preparar comidas brasileiras para oferecer ao namorado.

Às vezes eu chamo amigos brasileiros e outros daqui pra comer em casa, aí eu faço algo brasileiro pra que eles conheçam. Alguns deles já conhecem, então, quando eu os convido, eles me pedem para fazer aquele prato. [...] Isso geralmente acontece em momentos especiais e festivos, como, por exemplo, há dois anos atrás, no 
aniversário do meu namorado, que é francês, eu fiz caldinho de feijão e era inverno. Todo mundo adorou, não conheciam. Sempre que tenho oportunidade, faço alguma comida brasileira para a família dele [...] eles adoram [...] (Maria Clara, em entrevista em 5 de dezembro de 2018).

Quase todos os alimentos utilizados por Maria Clara para a feitura dos pratos brasileiros são facilmente encontrados por ela nos supermercados e lojas afro-latinas, sediadas em Barcelona, como aquelas supramencionadas anteriormente, outros nem tanto, como é o caso da couve, que "[...] aqui é muito difícil de encontrar, assim como a mandioquinha. No Brasil, eu comia muito, na casa da minha mãe sempre tinha cozida, ou sopa, ou purê de mandioquinha. Sinto muita saudade da couve e da mandioquinha". (Maria Clara em entrevista em 5 de dezembro de 2018). Outros alimentos são trazidos por ela do Brasil: "eu congelo o catupiry e trago congelado em bolsinha térmica, embaixo, na mala. Já trouxe cachaça também, chocolate bis, paçoca e café [...]”. (Maria Clara em entrevista em 5 de dezembro, 2018).

Outra imigrante brasileira que vive há 12 anos em território catalão é Elza Ortiz, que é natural de Porto Velho/ Rondônia e tem 45 anos. Como as demais, se diz adaptada ao lugar e aprecia a cozinha catalã, mas, apesar disso, segue comendo à moda brasileira, em especial o arroz e o feijão. "Eu mesma faço minha comida porque o sabor dos alimentos daqui é diferente e, para tentar deixar a comida o mais próximo possível do sabor do Brasil, eu me aproprio de alguns temperos brasileiros que são vendidos nas lojas afro-latinas." (Elza Ortiz, em entrevista concedida em 18 de dezembro de 2018).

Sendo assim, parece que foi na tentativa de continuar com o gosto de sua comida de origem que, no dia 10 de dezembro de 2018, ao retornar do Brasil, onde esteve por 30 dias de férias, Elza trouxe em sua mala duas iguarias que, segundo ela, não são encontradas na Catalunha, a saber, 1 quilo de charque e 1 quilo de calabresa. Com esta última, Elza fez um risoto, já o charque ajudou na composição de uma feijoada preparada e oferecida por ela, no dia 18 de novembro de 2018, para a qual fui convidado. Afora o charque, todos os demais ingredientes, particularmente aqueles derivados de porco, foram facilmente adquiridos nos mercados de Barcelona, conforme mostra a imagem 24.

Imagem 24 - O porco nos balcões de Barcelona

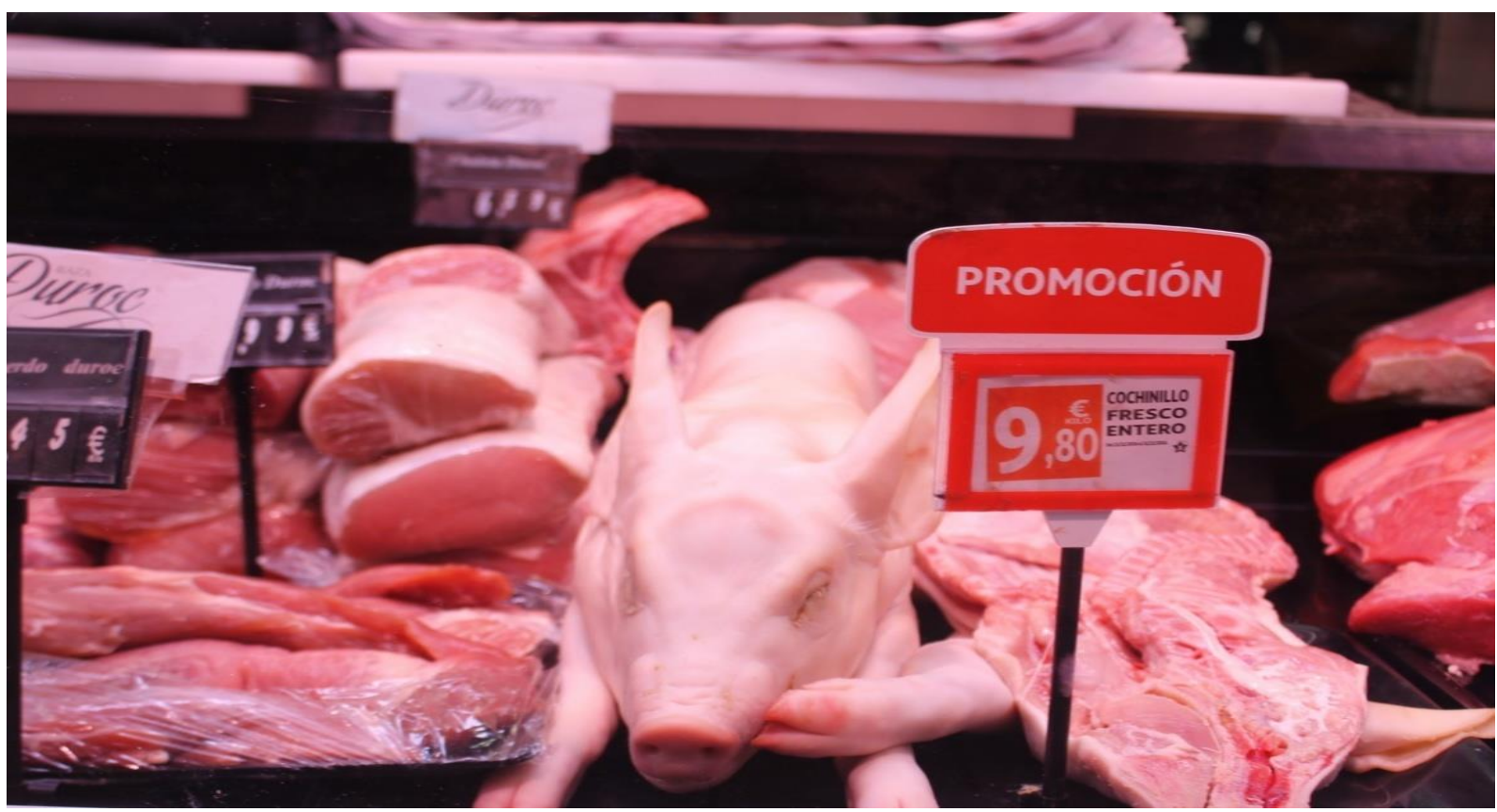

Fonte: arquivo do autor, 2018. 
A facilidade na aquisição dos referidos derivados se explica pelo fato de a carne de porco e seus derivados serem deveras apreciados pelos catalães e por isso os diversos cortes da carne do animal, ou ele mesmo, são facilmente encontrados nas prateleiras e balcões dos açougues e dos supermercados daquele território.

Outra modalidade do suíno constantemente presente nas prateiras, balcões e corredores dos supermercados é o Jamón, conforme mostram as imagens 25 a 27. Talvez este seja, dentre os alimentos derivados do suíno, o mais comum na dieta de Barcelona, principalmente os bocadillos de Jamón, que são os preferidos, nos lanches e merendas, entre os jovens estudantes primários e universitários, mas isso não significa que os adultos não o apreciem também.

Diferentemente da Catalunha, no Brasil, a carne de porco aparece como um alimento "marginal". Não se apresenta com regularidade nos mercados e nas mesas, não é comida do cotidiano, ao menos no território paraense, onde o animal e tudo o que dele deriva são classificados como comida reimosa. Mas afinal o que é uma comida reimosa?

Imagens 25 a 27 - O Jamón, protagonista do comer catalão

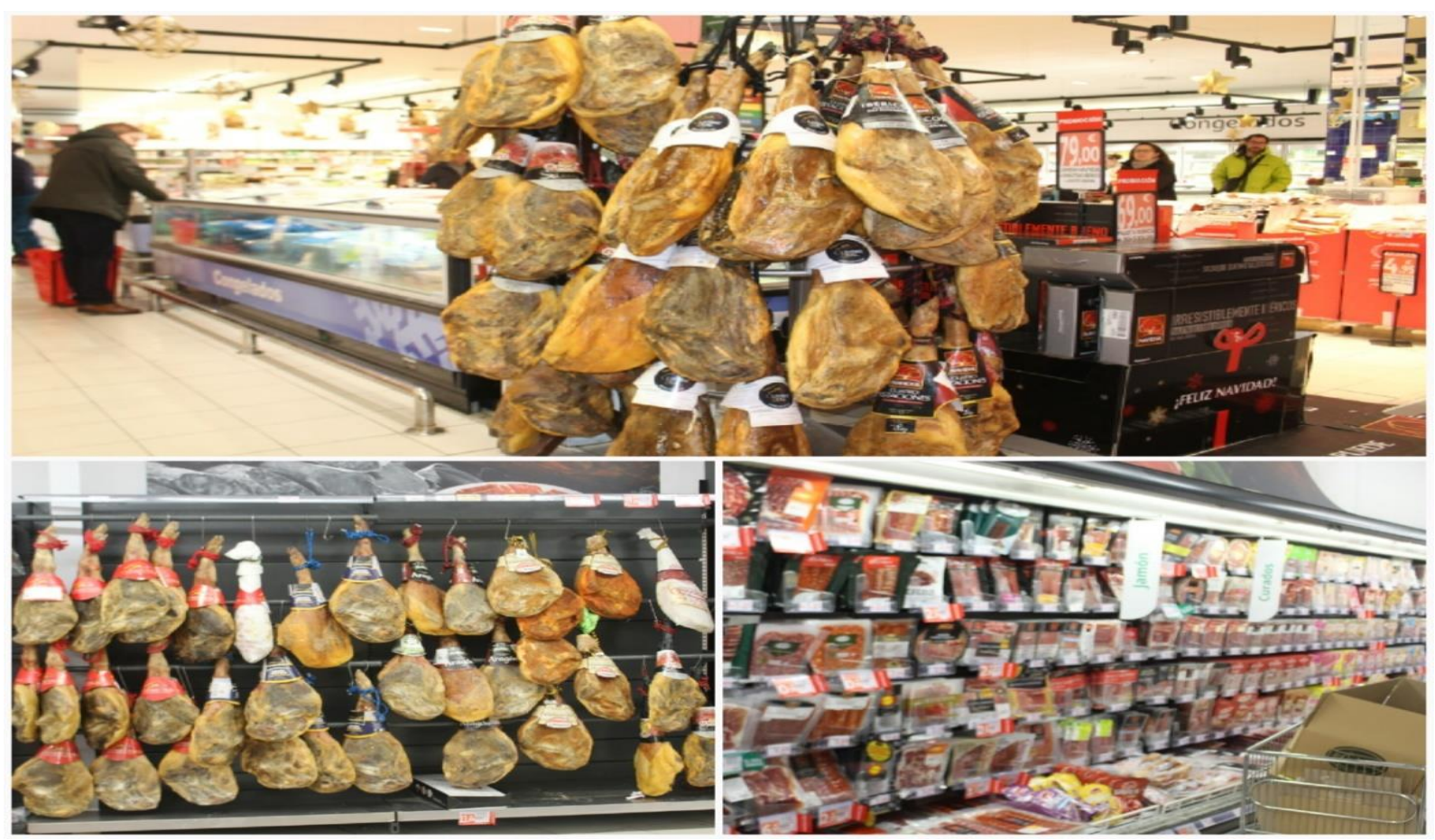

Fonte: arquivo do autor, 2018.

Uma comida é reimosa quando está associada a um determinado tabu alimentar, ou seja, são alimentos proibidos, ao menos temporariamente, providos da "[...] reima (do grego rheum = fluido viscoso), utilizada para classificar o grau de segurança dos animais selvagens e domésticos para o consumo" (SILVA, 2017, p. 127).

A reima é caracterizada por um sistema classificatório de oposições binárias entre alimentos perigosos (reimosos) e não perigosos (não reimosos), sendo aplicado às pessoas em estados físicos e sociais de liminaridade ou estados de representação ritual e simbólica de transição ou passagem, como enfermidades, menstruação e pósparto (MURRIETA, 1998 apud SILVA, 2017, p. 127). 
No Pará, em particular nas comunidades rurais desse estado, a reima é uma categoria advinda da sabedoria popular com significativas implicações no comportamento alimentar daquele povo. Além da carne de porco, a carne de pato, o caranguejo, o camarão, os peixes de pele, os ovos, dentre outros, são proibidos em determinados estados patológicos dos comensais paraenses, sob pena de serem acometidos por agravações inflamatórias de ulcerações e feridas cirúrgicas, potencializando o processo de supuração da área suturada no corpo, que podem ser seguidas de reações alérgicas.

Dito isso, reporto-me agora à última experiência por mim testemunhada durante este tempo de pesquisa, ocorrida no dia 8 de dezembro de 2018, e foi protagonizada por Maria Clara e seus alunos, do curso de Nutrição e Tecnologia de Alimentos, do Campus de La Alimentación, da Universidad de Barcelona.

Durante o primeiro semestre de 2018, Maria Clara ministrou a disciplina Antropologia da Alimentação e como parte do processo avaliativo, os referidos alunos empreenderam um trabalho de campo, onde entrevistaram imigrantes das mais variadas nacionalidades, inclusive brasileiros que vivem em Barcelona. $\mathrm{O}$ referido trabalho tinha por objetivo investigar os aspectos socioantropológicos e nutricionais do comportamento alimentar dos imigrantes entrevistados. Os resultados da investigação foram socializados pelos estudantes, na modalidade seminário, no último dia letivo, em 18 de dezembro de 2018.

Ao final dos seminários, as classes foram contempladas com uma mostra gustativa oferecida pela Maria Clara. No cardápio, brigadeiros e farofa, conforme mostrado nas imagens de 28 a 30. As manifestações e reações dos alunos frente às iguarias foram, a princípio, de curiosidade, seguidas de estranhamento - já que, para quase todos, aquele era o primeiro contato com aqueles alimentos - e, por fim, de satisfação manifestada em expressões como: "que rica, muy buena, boníssima, que buena."

Disse que a comida brasileira parecia estranha a quase, mas não a todos, isso porque entre os estudantes estava Maiellen Oro Bozzini, que tem 25 anos, de nacionalidade Argentina, mas vive em Barcelona desde a infância, a quem a cozinha brasileira parece familiar, "me encanta la comida brasileña. Ya comi tapioca, coxinhas, pan de queso, la feijoada, frijoles negros con arroz, barbacoa de picanha, pastel, brigadeiros." (Maiellen em entrevista, em 5 de dezembro de 2018).

Faz um ano e meio que Maiellen conheceu Beatriz, que é brasileira, e sua amiga, a qual vive em Barcelona com a família. Foi Beatriz quem lhe apresentou o paladar brasileiro e desde então, ao menos três vezes ao mês, sua dieta é povoada pela comida brasileira, ora degustada na casa de Beatriz, principalmente aos domingos, ora em sua própria casa, "Mi madre me prepara frijoles negros con arroz" (Maiellen em entrevista, em 5 de dezembro de 2018), ora no restaurante La Carioca, onde ela vai com Beatriz para comer tapioca.

A título de finalização, torna-se necessário frisar que o gosto da e pela comida brasileira e paraense parece ser o vetor das experiências de comensalidades empreendidas por Cynara, Elza, Maria Clara, e tantos outros imigrantes brasileiros e paraenses em Catalunha, que assim fazem pelo desejo de "[...] matar a saudade de casa, sentir-se em casa sem estar nela. É mais pra ter um contato, manter essa relação e sentir o gostinho do Brasil." (Maria Clara em entrevista em 5 de dezembro de 2018). Assim, um diálogo com os pressupostos socioantropológicos (BOURDIEU, 1988, FISHLER, 1995 e CONTRERAS; GRACIA, 2011) sobre o gosto ajudaria no entendimento das experiências comensais de meus interlocutores. 
Imagens 28 a 30 - Mostra gustativa na turma de Maria Clara

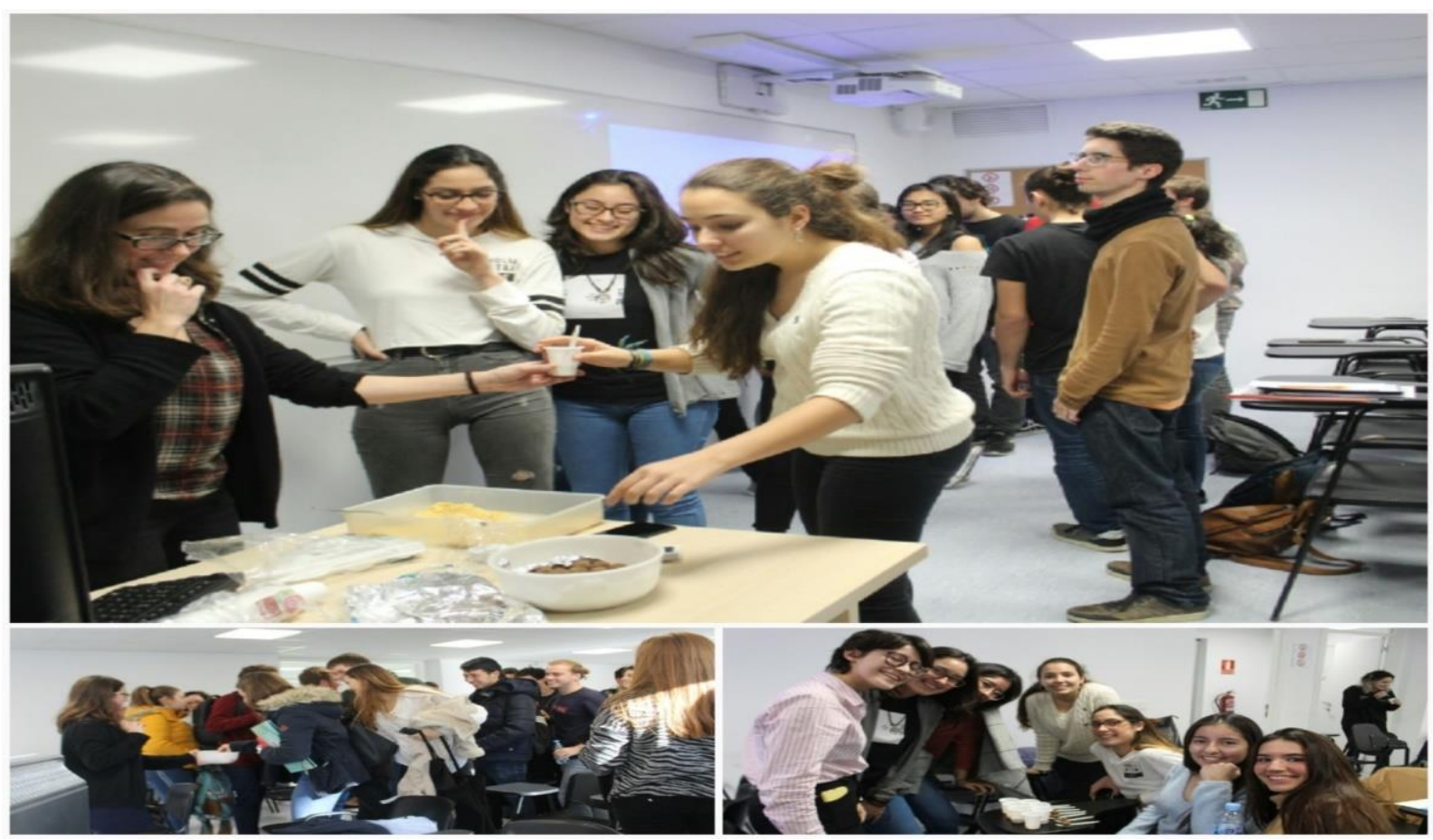

Fonte: arquivo do autor, 2018.

Para Bourdieu (1988), os gostos, ao mesmo tempo em que expressam a identidade sociocultural de classes ou subclasses, reproduzem a distinção entre elas, pois, por mais que aparentemente as escolhas sejam feitas mediante gostos individuais, elas estão condicionadas àquilo que o autor chama de capital econômico e simbólico específico. Sendo assim, as escolhas, as preferências e gostos seriam previsíveis, porque seus conteúdos estariam condicionados por um estilo de vida. Assim, os gostos, inclusive os alimentares, seriam elaborados no bojo da transmissão e da reprodução social.

Em sua análise, Bourdieu contrapõe os gostos das classes populares - gostos de "necessidades", com os gostos das classes altas, gosto de luxo ou de liberdade. Nas primeiras classes, o gosto finda a ideia da necessidade como atributo, como um dom, que contribui para que as comidas econômicas e nutritivas potencializem a reprodução da força de trabalho imposta a um baixo valor. De outro modo, os gostos de luxo, notados como atributos próprios daqueles sujeitos cujas condições materiais de existência nada têm a ver com a necessidade, mas estão intrinsecamente relacionados à liberdade ou facilidade disponibilizadas pelo capital.

Nessa lógica, Bourdieu defende a ideia de que o conteúdo das preferências que compõem o gosto de necessidade é determinado pelas relações de produção, quando os trabalhadores tendem a manifestar preferências pelos alimentos tidos como mais baratos e mais nutritivos, isto é, as classes populares tendem a comer, com mais frequência, aqueles alimentos que lhes proporcionam maior sensação de saciedade, por um custo menor. Por outro lado, no gosto de liberdade, o conteúdo das preferências é definido em função da arbitrariedade, ou seja: o gosto por alimentos mais leves e refinados deriva das pretensões dos estratos ascendentes e da distinção das classes dominantes.

Por outro lado e, de certo modo, em contraposição às prerrogativas de Bourdieu, Fishler (1995), assevera que os gostos alimentares são construções imbricadas nas dimensões palatáveis e olfativas, que são próprias de cada alimento, que, em diálogo com determinados contextos culturais, são elaborados, internalizados e coletivizados. Portanto, supõe-se que o gosto e todas suas implicações, as escolhas, as variações, incorporações e transformações dos 
comportamentos alimentares não decorrem necessariamente de uma ordem hierárquica, ou da competitividade entre classes, como sugere Bourdieu (1988). Elas resultam, antes, dos movimentos e das trajetórias vivificadas pelos sujeitos, desde a primeira infância, na dinâmica do grupo a que pertencem.

Pautado nos pressupostos preconizados por Fisheler (1995), considero que os gostos alimentares são situacionalmente forjados, isto é, “[...] dependem estritamente dos costumes alimentares [...]" (CONTRERAS 2011, p. 126), que estão em constante elaboração nos fluxos e movimentos da dinâmica da vida (INGOLD, 2015).

\section{CONSIDERAÇÕES FINAIS}

Por fim, parece que as experiências com a cozinha brasileira e paraense, vivificadas pelos imigrantes no território catalão, são marcadas por certa dicotomia, pois, ao mesmo tempo que adensam um antigo debate da Antropologia, particularmente da alimentação, a qual afirma que entre as mudanças exigidas pela vida, talvez nenhuma seja tão resistente quanto as inerentes aos gostos alimentares, também demonstram que poucos aspectos do fazer humano são tão suscetíveis ao encontro do Outro quanto o desejo de experimentar o gosto da cozinha alheia.

Parece que é nesse processo, de continuidade e descontinuidade, que a adaptação dos imigrantes ao gosto do Outro, no contexto catalão, se faz na medida em que suas experiências de comensalidade funcionam como recurso político que permite o encontro do Eu brasileiro e paraense com o outro que come diferente de mim. Essa dinâmica parece ser lócus privilegiado para a elaboração da diferença e evidenciado sentimento de pertença, funcionando como canal de afirmação, de resistência e preservação de costumes alimentares frente aos contextos globais que tendem a padronizar os aspectos da vida, inclusive os gostos alimentares.

\section{REFERÊNCIAS}

BOURDIEU, Pierre. La Distinción: critérios y bases sociales del gusto. Madrid. $1^{\text {a }}$. Ed.Taurus, 1988.

BRASIL. MINISTÉRIO DAS RELAÇÕES EXTERIORORES. (2015). Brasileirosno mundo. Brasília. Disponível em: www.brasileirosnomundo.itamaraty.gov.br. Acesso em 25 mar.2018.

CASCUDO, Luís da Câmara. História da alimentação no Brasil. São Paulo. $4^{\mathrm{a}}$. Ed. GLOBAL. 2011.

CONTRERAS, Jesús. GRACIA, Mabel. Alimentação, sociedade e cultura. Rio de janeiro. $1^{a}$. Ed. Fiocruz. 2011.

FISCHLER, Claude. Gastro-nomía y gastro-anomia. Sabiduría del cuerpo y crisis biocultural de la alimentación contemporánea. In: CONTRERAS, J. (Org.). Alimentación y Cultura: necesidades, gustos y costumbres. Barcelona. $1^{\text {a }}$. Ed.Universitat de Barcelona. 1995. INGOLD, Tim. Estar Vivo: ensaios sobre movimento, conhecimento e descrição. Petrópolis, RJ. 1 ${ }^{\text {a }}$.ed. Vozes. 2015.

PICANÇO, Miguel. Na roça, na mesa, na vida: uma viagem pelas trajetórias da mandioca, no e além do nordeste paraense. Belém. 1' ${ }^{\text {a }}$ Ed. Paka-Tatu. 2018. 
PICANÇO, Miguel De Nazaré Brito. Comida, consumo e identidade: Notas etnográficas por entre os processos migratórios da mandioca; do contexto brasileiro e paraense ao contexto europeu. Revista Mosaico, Rio de Janeiro, v. 8, n.13, p. 204 - 221, 2017. Disponível em: http://bibliotecadigital.fgv.br. Acesso em: 05 de set. 2018.

PRATS, Llorenç. La mercantilización del patrimonio: entre la economia turística y las representaciones identitarias. PH Boletín del Instituto Andaluz del Patrimonio Histórico, n. 58, p. 72-80, 2006. Disponível: http://www.iaph.es. Acesso em: 14 de jun. 2018.

ROCHA, Carla Pires vieir da; RIAL, Carmem Silva. Migração, Consumo Alimentar e Globalização: Fluxos entre Brasil e Europa. VII Encontro Nacional de Estudos do Consumo, III Encontro Luso-Brasileiro de Estudos do Consumo, I Encontro Latino-Americano de Estudos do Consumo. Pontifícia Universidade Católica do Rio de Janeiro (Puc-Rio). p, 111, 2014. Disponível em: www.estudosdoconsumo.com.br. Acesso em: 12 jul.2017.

SERRA, Joan Ribas. Vi, Política i Espectacle: Procés de patrimonialització de la Cultura del Vi a la denominación D’origen Alella. Barcelona/Es, 1ª . ed. UOC. 2014.

SILVA, Andréa Leme da. Comida de gente: preferências e tabus alimentares entre os ribeirinhos do Médio Rio Negro (Amazonas, Brasil). Revista de Antropologia, São Paulo, USP, V. $50 \mathrm{~N}^{\circ}$ 1, p. 127- 179, 2007. Disponível em:

http://www.scielo.br/scielo.php?script=sci_arttext\&pid=S003477012007000100004. Acesso em: 08 de jul. 2018.

WINTER, Cecilia Pérez. Patrimonialización, Turistificación y autenticidade em Exaltación de la Cruz, Argentina. Estudios y Perspectivas em Turismo, v. 22, p. 785-804, 2013.

Disponível em:

Www.scielo.org.ar/scielo.php?script=sci_arttext\&pid=S18511732201300040009. Acesso em: 20 de set. 2018. 